\title{
DILEMA ETIS PADA CALON AUDITOR: SEBUAH EKSPERIMEN
}

\begin{abstract}
The ethical dilemma is a condition often encountered by a person when engaged in a relationship that leads to fiduciary responsibility. In fact, this is often faced by the accounting profession when giving his services should be able to avoid conflict of interest. Therefore, this study was conducted on accounting students who have obtained an ethical understanding that acts as a potential auditor. Respondents in this study are accounting students level 3 in accounting majors in the Faculty of Economics Unswagati. This study is conducted through scenarios of cases relating to work or tasks that can lead to actions that conflict with ethical principles of accountants. Where accountants are supposed to apply ethical principles to be dilemma with the existence of such work. Through the scenario of the case, accounting students give their perception whether to perform tasks that are not according to their competence and limited time or the student will refuse the job. The results showed that for accounting students who have gained an understanding of ethics tend to consider many things and find solutions before performing tasks that are less in accordance with the competencies they have. Therefore, it can be concluded that the value of students who have gained a higher ethical understanding.
\end{abstract}

Keywords: ethical dilemma, professional principles, integrity, competence and professional caution

\section{PENDAHULUAN}

Dalam sebuah perusahaan, manajer dipandang sebagai pihak yang mempunyai keleluasaan untuk mengelola sumber daya yang dimiliki oleh perusahaan dan mempertanggungjawabkannya kepada principal. Hal ini sesuai dengan pendapat Wolk et.al. $(1989,42)$ bahwa dalam hubungan agency yang melibatkan agen (manajer) dan principal (investor) mencakup adanya kepentingan untuk meningkatkan kesejahteraan masingmasing. Principal mengharapkan bahwa investasi yang dilakukan akan menghasilkan return yang selalu meningkat, sedangkan manajer juga selalu berharap untuk memperoleh bonus dan insentif yang meningkat. Kondisi demikian yang dapat menimbulkan adanya asimetri informasi, bahwa informasi yang dimiliki oleh principal berbeda dengan informasi yang dimiliki oleh manajer.

Akuntan sebagai pihak yang independen berperan penting untuk mengurangi masalah agensi tersebut. Melalui jasa yang diberikan, akuntan diharapkan bersikap independen dan menjaga integritasnya. Meskipun dalam faktanya, akuntan sering dihadapkan pada situasi yang melibatkan konflik interest, sehingga akuntan tersebut dapat juga mengalami dilemma etis. Dilemm etis merupakan situasi yang melibatkan konflik prinsip perilaku etis dan kompleks karena tidak tersedia arahan yang jelas bagaimana untuk bertindak dan merespon masalah yang spesifik (Kitchener, 1984).

Fenomena pelanggaran etika bisnis maupun profesi akuntan yang mencakup tindakan korupsi maupun praktik akuntansi yang tidak sesuai semakin berkembang. Hal ini ditandai dengan banyaknya skandal akuntansi yang melibatkan manajemen perusahaan maupun profesi akuntan. Beberapa skandal akuntansi diantaranya kasus Enron yang melibatkan KAP Arthur Andersen dan kasus Lehman Brother yang melibatkan 
KAP Ernst \& Young. Hal ini menunjukkan bahwa manajemen perusahaan dan akuntan yang terlibat cenderung mengabaikan nilai-nilai etika.

Dilema etis menjadi salah satu hal menantang yang akan dihadapi oleh akuntan ketika memberikan jasanya. Oleh karena itu, mahasiswa akuntansi sebagai calon auditor diharapkan dapat memahami nilai-nilai etika yang harus diimplementasikan oleh seorang akuntan, sehingga dapat mengambil sebuah keputusan yang etis. Prinsip etika yang harus dijaga oleh seorang akuntan mengacu pada kode etik akuntan Indonesia yang menjelaskan bahwa akuntan harus melakukan tanggung jawab profesi, kepentingan publik, objektif, menjaga integritas, kerahasiaan, kompetensi dan kehati-hatian profesional, berperilaku profesional dan standar teknis.

Dalam menghadapi kondisi dilemma etis, individu akan mempertimbangkan banyak hal untuk mencoba mengambil sebuah keputusan yang etis. Hal ini juga tergantung pada karakteristik individu tersebut, apakah termasuk dalam kategori egoism, utilitarian atau deontology. Jika individu tersebut mempunyai karakter hanya mementingkan kepentingan pribadinya, maka disebut egoism. Sedangkan jika perilaku yang ditunjukkan agar bermanfaat bagi orang banyak dan memikirkan konsekuensi dari keputusannya, maka individu tersebut termasuk dalam tipe utilitarian. Jika tindakan yang dilakukan hanya mengacu pada pertimbangan dan aturan tertentu, maka individu tersebut masuk dalam kategori deontology.

Berbagai penelitian yang mengkaji tentang dilemma etis telah dilakukan. Penelitian mengenai etika bisnis mencakup tiga kategori dari ethical dilemma : coercion and control (CC), conflict of interest (Cl) dan personal integrity (PI). Menurut De George (1999), bahwa CC melibatkan adanya perlawanan atau ancaman - secara fisik maupun emosional - dan mencoba untuk memaksa individu untuk membuat keputusan yang spesifik (Fritzsche \& Becker, 1984). Cl melibatkan benturan dan konflik kepentingan antara individu dan beberapa pihak. PI melibatkan isu yang berhubungan dengan nurani dan perasaan seseorang mengenai tindakan yangbenar dan tindakan yang salah (Fritzsche \& Becker, 1984).

Penelitian yang dilakukan oleh Ho dan Lin (2011) mengkaji tentang keputusan etis mahasiswa pada dua negara yang mempunyai perbedaan budaya, yaitu Amerika dan Taiwan. Hasilnya menunjukkan bahwa terdapat perbedaan dalam hal ethical awareness, ethical development dan ethical intention yang ditunjukkan melalui persepsi mahasiswa terhadap situasi yang spesifik.

Sulistyowati dan Yulianto (2014) melakukan penelitian melalui eksperimen mengenai keputusan yang diambil oleh mahasiswa apakah akan menjadi whistleblower atau tidak ketika dihadapkan pada scenario yang melibatkan dilemma etis. Hasilnya menunjukkan bahwa keputusan yang diambil oleh mahasiswa tersebut untuk menjadi whistleblower dipengaruhi oleh saran dari teman terdekat, kewajiban moral dan biaya keuangan personal. Namun mahasiswa kurang mempertimbangkan faktor konsekuensi ketika akan berperan sebagai whistleblower.

Rosnidah et al. (2016) dan Rosnidah et al. (2017) mengkaji keputusan etis yang dilakukan oleh calon auditor dan auditor pemerintah berdasarkan idealism, relativisme dan intensitas moral. Penelitian tersebut mendasarkan pada Theory of Planned Behavior dan Theory of Reasoned Action. Hasil penelitian yang dilakukan 
terhadap calon auditor dan auditor pemerintah menunjukkan bahwa idealism, relativisme dan intensitas moral berpengaruh positif terhadap keputusan etis.

Esa dan Zahari (2015) meneliti hubungan antara personal traits dan persepsi mahasiswa akuntansi terhadap etika dan love of money menunjukkan bahwa personality traits berpengaruh terhadap etika dan love of money. Onyebuchi (2011) meneliti persepsi mahasiswa akuntansi dan mahasiswa non akuntansi mengenai etika sebelum skandal Enron dan setelah skandal Enron. Hasilnya menunjukkan bahwa semua mahasiswa akuntansi memberikan persepsi yang etis, sedangkan untuk mahasiswa non akuntansi ada 7\% mahasiswa yang berpersepsi tidak etis.

Abbaszadeh (2012) meneliti persepsi mahasiswa akuntansi terhadap etika akuntan di Iran dan United Kingdom. Hasilnya menunjukkan bahwa ditinjau dari dimensi etika menurut Hofstede terdapat perbedaan persepsi antara mahasiswa di Iran dengan mahasiswa di United Kingdom. Berdasarkan scenario Accounting Specific Defining Issues Test (ADIT), menunjukkan bahwa terdapat perbedaan persepsi mengenai ethical development. Terdapat perbedaan ethical sensitivity, ethical orientation dan intention. Individualism/ collectivisme dan masculinity/femininity lebih berpengaruh terhadap persepsi etis mahasiswa dibandingkan dengan pengaruh dimensi Hofstede.

Dengan banyaknya skandal keuangan dalam perusahaan yang melibatkan peran akuntan menyebabkan terdiskreditnya profesi akuntan. Oleh karena itu, focus dalam penelitian ini adalah mengkaji secara mendalam melalui studi kasus pada mahasiswa akuntansi sebagai calon auditor dengan scenario kasus yang berkaitan dengan dilemma etis. Prinsip etika yang perlu dipegang oleh seorang akuntan ketika menghadapi masalah ethical dilemma adalah tetap menjaga integritas, confidentiality dan perilaku profesionalnya. Integritas merupakan kualitas yang melandasi kepercayaan public dan menjadi patokan (benchmark) bagi anggota dalam menguji semua tindakan yang diambilnya. Jika tindakan yang dilakukan oleh akuntan dianggap tidak sesuai dengan standar etika yang dimiliki, maka dapat menimbulkan turunnya kepercayaan masyarakat terhadap profesi akuntan tersebut. Kompetensi dan kehati-hatian professional merupakan prinsip yang harus dipegang oleh seorang akuntan, dimana akuntan mempunyai kewajiban untuk mempertahankan pengetahuan dan ketrampilan professional pada tingkat yang diperlukan untuk memastikan bahwa klien memperoleh manfaat atas jasa yang kompeten dan selalu mengikuti perkembangan praktik yang terkini.

Banyaknya fenomena skandal keuangan yang melibatkan profesi akuntan menunjukkan bahwa perlu dilakukan analisis lebih mendalam terhadap perilaku etis mahasiswa akuntansi sebagai calon auditor. Beberapa penelitian terdahulu mengkaji keputusan etis auditor maupun calon auditor dengan metode yang berbedabeda, sehingga menghasilkan hasil yang beragam. Penelitian ini dilakukan berdasarkan pada penelitian terdahulu yang dilakukan oleh Johari \& Saidi (2013), Rosnidah et al. (2016; 2017) bertujuan untuk menekankan pentingnya memegang nilai-nilai etika ketika seorang mahasiswa akuntansi dihadapkan pada scenario kasus yang menimbulkan dilemma etis. Mahasiswa akuntansi sebagai calon auditor diharapkan dapat memahami nilai-nilai etika seorang akuntan semenjak dalam masa perkuliahan. Sehingga ketika mahasiswa telah lulus dan berpraktik sebagai akuntan akan tetap menerapkan prinsip etika seorang akuntan. 
Fokus penelitian adalah pemusatan focus kepada intisari penelitian. Dalam penelitian ini, yang menjadi focus adalah bagaimana tindakan atau reaksi mahasiswa akuntansi ketika menghadapi scenario kasus yang berhubungan dengan dilemma etis. Riset terdahulu yang dilakukan oleh Johari \& Saidi (2013), Rosnidah et al. (2016) dan Rosnidah et al. (2017) mengkaji tentang keputusan etis auditor dan calon auditor, serta hasil penelitian Sulistyowati \& Yulianto (2014) mengkaji keputusan mahasiswa akuntansi dalam menghadapi kasus skandal keuangan yang terjadi dalam perusahaan. Berdasarkan referensi tersebut, maka penelitian ini dilakukan melalui studi kasus berkaitan dengan scenario kasus yang melibatkan dilema etis.

Berikut daftar pertanyaan yang menjadi focus dalam penelitian ini :

1. Bagaimana pemahaman mahasiswa terhadap prinsip etika akuntan?

2. Bagaimana pengetahuan mahasiswa berkaitan dengan skandal akuntansi yang melibatkan profesi akuntan?

3. Bagaimana sikap yang ditunjukkan oleh mahasiswa ketika menghadapai tindakan yang menimbulkan dilema etis?

4. Apakah keputusan yang diambil oleh mahasiswa berkaitan dengan scenario dilema etis telah sesuai dengan nilai-nilai etika?

\section{KERANGKA TEORITIS DAN PREPOSISI PENELITIAN}

Kohlberg's Ethical Cognitive Development Theory $(1969 ; 1981$; 1984) secara umum digunakan dalam memahami alasan seseorang dalam mengambil keputusan moral. Kohlberg (1969) mendefinisikan moral reasoning sebagai keputusan apakah tindakan tersebut benar atau salah, pengembangan moral menunjukkan tingkat kedewasaan dalam moral reasoning. Teori tersebut juga menjelaskan bahwa subjek moral reasoning sebagai alasan yang digunakan seseorang ketika menghadapi dilemma etis.

Berdasarkan Kohlberg theory, maka tindakan atau keputusan yang dilakukan oleh mahasiswa ketika menghadapi scenario kasus yang berhubungan dengan dilemma etis akan dikaji berdasar perkembangan moral yang dimilikinya. Dalam penelitian kualitatif, teori yang dikemukakan bersifat sementara dan akan berkembang atau berubah setelah peneliti berada di lapangan. Sesuai dengan penelitian terdahulu yang dilakukan oleh Sulistyowati dan Yulianto (2014) dan Rosnidah et al. (2014) yang mengkaji keputusan mahasiswa berdasarkan Theory of Reasoned Action (TRA) yang dikembangan oleh Ajzen \& Fishbein (1980), serta penelitian Rosnidah et al. (2016) yang menggunakan Theory of Planned Behavior (Ajzen, 1988) untuk memprediksi keputusan etis auditor dan calon auditor.

Menurut Kitchener (1984), dilemma etis merupakan situasi yang melibatkan prinsip perilaku etika yang kompleks dan bertentangan, karena tidak ada arahan yang jelas tentang bagaimana bertindak atau merespon masalah yang spesifik. Hunt dan Vitell (1986) berpendapat bahwa sangat penting mempelajari ethical dilemma dan ethical reasoning, karena sangat berkaitan dengan tindakan etis yang dilakukan oleh seseorang.

Menurut penelitian dalam etika bisnis, terdapat tiga kategori dalam ethical dilemma : coercion and control (CC), conflict of interest (Cl) dan personal integrity (PI). CC melibatkan tantangan dan ancaman baik 
secara fisik maupun emosional (De George, 1999) - menunjukkan adanya tantangan bagi individu dalam membuat keputusan yang spesifik (Fritzsche \& Becker, 1984); (2) Cl melibatkan benturan dan konflik interest antara individu atau beberapa pihak dan (3) PI mencakup isu-isu yang berhubungan dengan hal yang benar atau salah (Fritzsche \& Becker, 1984). Nilai dan prinsip etika yang dimiliki akan mengarahkan individu dalam mengambil keputusan yang etis, ketika dihadapkan pada kondisi dilema etis (McClain, 2012). Prinsip etika mencakup beberapa hal, diantaranya otonomi, benefisiensi, confidentiality, justice dan toleransi.

Keputusan merupakan suatu pilihan apakah akan melakukan tindakan tertentu atau tidak melakukan tindakan tertentu (Baron, 2000). Keputusan yang diambil oleh seseorang tentunya sangat berkaitan dengan tujuan yang telah ditetapkan dan disertai adanya keyakinan untuk mencapai tujuan tersebut. Ethical reasoning sangat penting bagi sesorang yang menghadapi situasi dilemma etis. Keyakinan etis dijarakan kepada seseorang semenjak usia dini dan menjadi keyakinan mendasar yang paling penting. Hal ini tercermin dalam nilai moral seseorang ketika akan mengambil keputusan dengan mempertimbangkan pengaruhnya bagi orang lain.

Menurut Simnett (1996), tingkat pengalaman yang dimiliki oleh seseorang yang mengambil keputusan berpengaruh terhadap keakuratan keputusan yang dibuatnya tersebut. Keuntungan dari pengalaman tersebut adalah bahwa auditor mengetahui informasi yang akan dicari dan dengan pengetahuan yang lebih luas, maka auditor dapat mengelola informasi yang relevan tersebut agar dapat digunakan secara efektif. Hal ini diperkuat dengan pendapat Tsui (1996) bahwa tingkat ethical reasoning auditor yang lebih tinggi cenderung dapat meminimalisir terjadi tindakan tidak etis yang dilakukan oleh auditor.

Dalam penelitian ini, mahasiswa akuntansi sebagai calon auditor diharapkan mempunyai keyakinan etis yang tinggi. Ketika menjadi seorang akuntan dan menghadapi situasi yang melibatkan dilemma etis, maka mahasiswa sebagai calon akuntan ketika akan mengambil sebuah keputusan agar mempertimbangkan konsekuensi keputusan tersebut dan disesuaikan dengan nilai-nilai etika. Stuart merekomendasikan sebuah model keputusan yang etis melibatkan 4 langkah : akuntan harus mengakui bahwa dilema etis tersebut ada, akuntan harus mengidentifikasi bagian yang tertarik dengan kondisi dilema etis, akuntan harus menentukan alternative dan mengevaluasi masing-masing pengaruh masing-masing alternative terhadap tiap pihak, akuntan harus memilih alternative yang terbaik.

Meningkatnya jumlah skandal bisnis yang melibatkan profesi akuntan memberikan konsekuensi pada menurunnya tingkat kepercayaan masyarakat. Dalam hal ini, badan profesi akuntan dan institusi pendidikan sebagai tempat dibentuknya calon akuntan diharapkan dapat mendukung untuk menanamkan nilai-nilai etika. Mahasiswa akuntansi sebagai calon akuntan, ketika dihadapkan pada scenario kasus yang berhubungan dengan dilema etis diharapkan tetap memegang prinsip etika akuntan, yaitu integritas, kompetensi dan kehati-hatian serta perilaku professional. Oleh karena itu, akuntan harus dapat bertindak jujur dan tegas dalam mengambil keputusan yang melibatkan dilemma etis. Mahasiswa harus memahami bahwa menjadi akuntan harus selalu mengembangkan kompetensi keahlian teknis serta bertindak hati-hati ketika akan mengambil keputusan. Perilaku professional juga perlu ditegakkan agar tidak terpengaruh atas kepentingan pihak 
tertentu. Berdasarkan penjelasan tersebut, maka gambar kerangka pemikiran dalam penelitian ini ada pada gambar 1 lampiran.

\section{Proposisi}

Berdasarkan kerangka pemikiran di atas, untuk mencapai tujuan penelitian maka proposisi yang diajukan adalah :" Apabila scenario kasus yang berkaitan dengan dilemma etis dapat dianalisis secara mendalam berdasarkan prinsip etika yang harus dipegang oleh seorang akuntan, maka pemahaman mahasiswa serta standar etika yang dimiliki oleh mahasiswa akan meningkat".

\section{METODE PENELITIAN}

\section{Asumsi Filosofis Penelitian Kualitatif}

Metode penelitian ini didesain dalam bentuk penelitian kualitatif yang diarahkan mendiskripsikan fenomena yang terjadi berkaitan dengan scenario kasus mengenai dilemma etis. Mengeksplorasi dan mengartikulasikan penelitian kualitatif menunjukkan adanya fenomena moral yang mencerminkan etika yang dimiliki oleh seseorang. Mahasiswa akuntansi akan dinilai bagaimana sikapnya ketika diberikan ilustrasi scenario kasus yang berkaitan dengan dilemma etis. Hal ini dilakukan untuk meningkatkan pemahaman etika serta menanamkan prinsip etika profesi akuntan semenjak mahasiswa masih dalam proses pembelajaran. Sehingga ketika memasuki dunia kerja, sebagai calon akuntan, mahasiswa akan terus mempertahankan dan meningkatkan pemahaman etis yang dimilikinya.

\section{Strategi Penelitian Kualitatif}

Penelitian ini menggunakan strategi studi kasus berupa eksperimen mengenai scenario tindakan yang menimbulkan dilemma etis. Scenario kasus tersebut mengadopsi dari CCAB Ethical Dilemmas Case Studies for Professional Accountants in Public Practice. Dalam hal ini, peneliti menyelidiki secara cermat suatu program, peristiwa, aktivitas, proses atau sekelompok individu. Kasus dibatasi oleh waktu dan aktivitas dan peneliti mengumpulkan informasi secara lengkap dengan menggunakan berbagai prosedur pengumpulan data berdasarkan waktu yang telah ditentukan (Stake, 1995) dalam Creswell (2010).

\section{Peran Peneliti}

Keterlibatan peneliti akan memunculkan isu-isu strategis, etis, personal dalam proses penelitian kualitatif (Locke et al., 2007 dalam Creswell (2010).

Dalam hal ini, peneliti merupakan dosen akuntansi yang mengampu mata kuliah audit dan mata kuliah etika bisnis dan profesi akuntansi. Dengan latar belakang tersebut, maka peneliti akan menjelaskan tentang standar audit serta etika yang yang harus dipegang oleh profesi akuntan. Sehingga dalam hal ini, partisipan akan lebih focus terhadap masalah yang berkaitan dengan etika akuntan.

Partisipan dalam penelitian adalah mahasiswa akuntansi di Unswagati yang telah menempuh mata kuliah 
auditing dan mata kuliah etika bisnis dan profesi akuntansi. Penelitian mengenai etika profesi akuntan sangat memberikan kontribusi bagi Badan Profesi Akuntan, dalam hal ini adalah Ikatan Akuntan Indonesia, serta bagi institusi pendidikan sebagai tempat menempa ilmu bagi calon akuntan. Bagi badan profesi, dengan adanya fenomena yang mendiskreditkan profesi akuntan, maka melalui penelitian ini diharapkan dapat mengurangi potensi terjadinya fraud yang dilakukan profesi akuntan, karena sebagai calon akuntan, mahasiswa akuntansi telah memahami prinsip etika yang harus dipertahankan meskipun menghadapi kondisi dilemma etis.

\section{Prosedur-prosedur Pengumpulan Data}

Subjek dipilih secara purposive, yaitu mahasiswa akuntansi yang telah menempuh mata kuliah auditing dan mata kuliah etika bisnis dan profesi akuntansi. Mahasiswa tersebut telah memperoleh pemahaman mengenai standar etika yang dimiliki oleh seorang akuntan. Oleh karena itu, penelitian kuantitatif tidak mengacu pada kuantitas narasumber, tetapi lebih menekankan kualitas dari informasi narasumber yang menjadi tokoh kunci.

Penelitian ini disertai dengan observasi dan mengumpulkan data sekunder berupa jumlah mahasiswa akuntansi yang telah menempuh mata kuliah auditing dan mata kuliah etika bisnis dan profesi akuntansi di Fakultas Ekonomi Unswagati Cirebon. Berdasarkan data mahasiswa akuntansi tingkat 3 berjumlah 310 mahasiswa dan sesuai dengan Slovin formula diperoleh sampel sebanyak 140 mahasiswa.

Observasi kualitatif dilakukan dalam penelitian ini, dimana peneliti langsung turun ke lapangan untuk mengamati perilaku dan aktivitas individu-individu di lokasi penelitian. Dalam pengamatan ini, peneliti merekam /mencatat baik dengan cara testruktur maupun semi terstruktur dan aktivitas-aktivitas dalam lokasi penelitian. Instrument penelitian yang utama dalam penelitian kualitatif adalah peneliti sendiri dengan melakukan wawancara secara langsung terhadap nara sumber yang telah ditetapkan oleh peneliti. Untuk memperoleh tingkat pemahaman etika mahasiswa akuntansi, maka peneliti akan menggali informasi yang mendalam melalui observasi maupun wawancara yang dilakukan.

\section{Prosedur-prosedur Analisis Data}

Berikut langkah-langkah yang dilakukan dalam analisis data penelitian:

1. Mengolah dan mempersiapkan data untuk dianalisis

Langkah ini melibatkan transkripsi wawancara, menscanning materi, mengetik data lapangan dan memilahnya sesuai sumber informasi.

2. Membaca keseluruhan data

Membangun general sense atas informasi yang diperoleh dan merefleksikan maknanya secara keseluruhan.

3. Menganalisis lebih detail dengan mengcoding data

Proses mengolah materi/informasi menjadi segmen-segmen tulisan sebelum memaknainya. 
Berikut susunan naratif dalam penelitian ini :

\section{Masalah-masalah Etis yang Akan Muncul}

Dengan penelitian yang dilakukan pada mahasiswa akuntansi sebagai calon auditor, melalui kenario kasus yang melibatkan dilemma etis dapat menimbulkan berbagai masalah-masalah etis yang muncul. Sesuai dengan teori etika, karakteristik individu dapat dilihat apakah termasuk dalam kategori egoisme, utilitarianisme atau deontology. Hal ini dapat dilihat dari reaksi dan tindakan mahasiswa ketika menghasapi scenario kasus yang melibatkan dilema etis.

Jika mahasiswa akuntansi sebagai calon auditor tersebut memberikan reaksi atau tindakan yang hanya menguntungkan dirinya sendiri, maka disebut egoism. Jika reaksi atau keputusan yang diambil dengan mempertimbangkan manfaatnya bagi orang lain, maka dikategorikan utilitarianisme dan jika hanya bertindak sesuai aturan maka disebut deontology.

\section{Pentingnya Penelitian}

Urgensi dari penelitian ini berkaitan dengan berbagai manfaat dilakukannya penelitian, diantaranya bagi institusi pendidikan yang berkaitan dengan pengembangan kurikulum di bidang akuntansi. Bagi badan profesi akuntansi berkaitan dalam penentuan kebijakan ataupun kemitraan dengan institusi pendidikan dalam rangka untuk meningkatkan kredibilitas profesi akuntan. Penelitian ini juga dapat dijadikan sebagai sumber referensi bagi mahasiswa dalam perkuliahan atau penyusunan karya ilmiah serta bagi penelitian selanjutnya yang mengkaji topik yang sama.

\section{Perubahan-perubahan advokasi/parsipatoris yang diharapkan}

Dengan dilakukannya penelitian ini, maka diharapkan terjadi perubahan-perubahan pada mahasiswa akuntansi sebagai calon auditor sekaligus partisipan. Perubahan yang diharapakan berkaitan dengan semakin meningkatnya kesadaran etika, mempunyai sensitivitas etis yang tinggi, serta mampu mempertahankan prinsip etika meskipun dihadapkan pada situasi yang melibatkan dilemma etis.

\section{HASIL DAN LUARAN YANG DICAPAI}

\section{Profil Responden}

Responden yang terlibat dalam penelitian ini adalah mahasiswa akuntansi di fakultas ekonomi yang telah menempuh mata kuliah etika bisnis dan profesi akuntansi (tingkat 3) Berdasarkan data yang diperoleh menunjukkan terdapat 310 mahasiswa tingkat 3. Penelitian ini melibatkan 140 mahasiswa tingkat 4, yaitu lakilaki sebanyak 45 dan perempuan sebanyak 95.

\section{Pemahaman mahasiswa terhadap prinsip etika akuntan}

Berdasarkan hasil wawancara dan observasi terhadap mahasiswa terkait pemahaman mahasiswa terhadap prinsip etika akuntan menunjukkan bahwa mahasiswa tingkat 3 yang telah menempuh mata kuliah auditing 
maupun etika bisnis dan profesi akuntansi mayoritas telah memahami prinsip etika yang harus dimiliki oleh seorang akuntan. Pernyataan tersebut dapat dilihat dari persepsi mahasiswa akuntansi ketika menganalisis scenario kasus yang berhubungan dengan dilemma etis pada sebuah perusahaan.

\section{Berikut ilustrasi kasus yang melibatkan Dilema Etis}

Anda merupakan seorang peserta pelatihan akuntansi pada tahun kedua yang melibatkan praktek dalam lingkup kecil. Peserta pelatihan yang lebih senior sedang cuti karena sakit, dan anda juga meninggalkan untuk cuti studi. Anda telah diberitahu oleh manajer anda, bahwa sebelum anda cuti, anda harus melengkapi pekerjaan rekonsiliasi yang cukup rumit. Deadline yang dianjurkan tidak realistis, karena pekerjaan yang dilakukan kompleks.

Anda berpikir bahwa anda tidak cukup berpengalaman untuk melakukan pekerjaan sendiri. Anda membutuhkan pengawasan tambahan agar tindakan anda sesuai dengan standar yang diminta dan manajer anda tidak memberikan dukungan yang penting. Jika anda mencoba untuk memenuhi pekerjaan yang mencakup jangka waktu yang diajukan tetapi gagal untuk memenuhi kualitas yang diharapkan, anda dapat menghadapi akibat / risiko setelah anda kembali dari cuti. Anda merasakan sedikit terintimidasi oleh manajer anda dan juga merasakan tekanan untuk melakukan apa yang dapat anda praktikkan dalam waktu yang menantang.

\section{Kunci prinsip fundamental yang dipengaruhi Integritas:}

Dapatkan anda menjadi terbuka dan jujur menghadapi situasi tersebut? apakah benar untuk mencoba memenuhi pekerjaan yang secara teknis diluar kemampuan anda, tanpa pengawasan yang memadahi?

\section{Kompetensi professional dan kehati-hatian:}

Apakah mungkin untuk memenuhi pekerjaan tanpa adanya waktu yang tersedia dan masih bertindak dengan rajin untuk mencapai kualitas output yang diminta?

\section{Perilaku professional:}

Dapatkah anda menolak untuk melakukan pekerjaan tanpa membahayakan reputasi anda dalam praktek tersebut? dengan alternative, dapatkah reputasi praktik menjadi memburuk jika anda mencoba untuk melakukan pekerjaan tersebut?

Mahasiswa tingkat 3 yang telah menempuh mata kuliah auditing serta etika bisnis dan profesi akuntansi mayoritas telah memahami prinsip etika yang harus dimiliki oleh seorang akuntan. Pernyataan tersebut dapat dilihat dari persepsi mahasiswa akuntansi ketika menganalisis scenario kasus yang berhubungan dengan dilemma etis pada sebuah perusahaan. Berikut rangkuman beberapa jawaban responden dalam mempersepsikan scenario kasus tersebut: 
Nama responden :

Tingkat : 3

Persepsi mengenai prinsip etika yang berkaitan dengan scenario kasus:

\section{Integritas}

Dapatkan anda menjadi terbuka dan jujur menghadapi situasi tersebut?

- Berusaha dulu untuk meminta bantuan kepada orang yang lebih mengerti agar diawasi dan dibimbing jika memang tidak mampu baru jujur kepada manajer jika tidak bisa.

Dapatkah reputasi praktik menjadi memburuk jika anda mencoba untuk melakukan pekerjaan tersebut?

- $\quad$ Tidak benar, seharusnya diawasi karena orang itu butuh bimbingan dan pengawasan agar dapat melaksanakan pekerjaan dengan baik.

\section{Kompetensi, Profesional dan Kehati-hatian}

Apakah mungkin untuk memenuhi pekerjaan tanpa adanya waktu yang tersedia dan masih bertindak dengan rajin untuk mencapai kualitas output yang diminta?

Tidak mungin, karena waktu yang sangat singkat akan mengurangi kualitas laporan apalagi orang tersebut masih belum paham dengan apa yang harus dikerjakan.

\section{Perilaku Profesional}

Dapatkah anda menolak untuk melakukan pekerjaan tanpa membahayakan reputasi anda dalam praktek tersebut?

- Tidak bisa menolak, karena jika menolak maka reputasi kita juga akan jelek dimata manajer.

Dapatkah reputasi praktik menjadi memburuk jika anda mencoba untuk melakukan pekerjaan tersebut?

- Bisa saja, jika kita mengerjakan dengan asal dan tidak banyak bertanya kepada orang yang mengerti dan mengerjakan tanpa pengawasan.

Berdasarkan persepsi mayoritas responden yang telah menempuh mata kuliah auditing serta etika bisnis dan profesi akuntansi terhadap scenario kasus yang berkaitan dengan prinsip fundamental akuntan menyatakan bahwa:

1. Dalam scenario kasus mahasiswa diberikan peran sebagai peserta pelatihan akuntansi yang belum berpengalaman, diminta oleh manajer untuk melakukan rekonsiliasi yang sangat rumit karena peserta pelatihan yang senior sedang cuti karena sakit. Mayoritas mahasiswa menjawab jujur bahwa mereka akan berusaha untuk berkonsultasi dengan orang lain yang mengerti pekerjaan tersebut dan meminta agar melakukan pendampingan ketika melakukan tugas dari manajer tersebut. Ketika mahasiswa diberi pertanyaan terkait reputasi burukyang diterima jika mereka mau melakukan pekerjaan tersebut, mayoritas mahasiswa menjawab bahwa tidak benar jika pekerjaan tersebut dapat memperburuk reputasi.

2. Dalam melakukan pekerjaan rekonsiliasi yang diberikan oleh manajer tanpa didukung dengan waktu 
yang mencukupi, serta adanya harapan dapat mencapai kualitas yang diminta. Mayoritas mahasiswa memberikan persepsi bahwa mereka tidak mampu menyelesaikan pekerjaan rekonsiliasi yang rumit dalam waktu yang singkat. Jika waktu yang disediakan singkat, sedangkan pekerjaannya kompleks, maka dikhawatirkan ada beberapa langkah dalam pekerjaan yang tidak dilakukan, sehingga dapat selesai dengan cepat atau yang disebut dengan premature sign off. Hal tersebut dapat dianggap sebagai perilaku yang menyimpang.

3. Ketika mahasiswa dalam scenario kasus berperan sebagai peserta pelatihan yang diberikan tugas yang rumit dari manajer maka mereka terkesan tidak mampu menolak pemberian tugas tersebut. Jika dikaitkan dengan reputasi, mayoritas memberikan persepsi bahwa jika mereka melakukan pekerjaan tersebut, maka dapat menimbulkan reputasi yang buruk.

Berdasarkan uraian penjelasan tersebut, maka mahasiswa akuntansi yang telah menempuh mata kuliah auditing serta etika bisnis dan profesi akuntansi menunjukkan bahwa ketika mereka akan memberikan persepsi terhadap scenario kasus yang menimbulkan dilemma etis, maka mahasiswa tersebut cenderung akan mempertimbangkan kriteria pengambilan keputusan yang etis. Diantaranya ketika diberi tugas yang rumit dan kompleks, maka akan mencoba mencari solusi dengan mencari teman lain yang dianggap mampu diajak untuk membantu dalam menyelesaikan tugas tersebut, karena merasa dirinya belum mempunyai kemapuan untuk melakukan tugas tersebut. Dengan terbatasnya waktu yang diberikan, mahasiswa merasa khawatir bahwa mereka tidak mampu mengerjakan semua prosedur dalam rekonsiliasi tersebut untuk mencapai waktu yang telah ditentukan. Mereka berusaha akan meminta waktu yang sesuai dengan tujuan agar semua prosedur pekerjaan dapat dilakukan dan mencapai hasil yang maksimal. Artinya dengan mengambil keputusan tersebut bahwa mahasiswa tingkat 3 cenderung memperhatikan five question approach, yaitu mengambil keputusan yang dipandang dapat menguntungkan semua pihak, legal, benar, wajar dan untuk keberlanjutan. Mahasiswa tersebut jika dipandang dari teori etika mempunyai karakter utilitarianisme, yaitu segala tindakannya memperhatikan kepentingan semua pihak.

\section{Pengetahuan mahasiswa berkaitan dengan skandal akuntansi yang melibatkan profesi akuntan}

Untuk mahasiswa tingkat 3 yang telah menempuh mata kuliah auditing maupun etika bisnis dan profesi akuntansi mayoritas mempunyai banyak pengetahuan terkait dengan skandal akuntansi yang melibatkan profesi akuntan, baik yang terjadi di luar negeri maupun di Indonesia. Mahasiswa mampu menjelaskan tentang kasus enron, kasus lehman brother, kasus worldcom, HIH Insurrance. Dalam penjelasan mahasiswa tersebut menyatakan bahwa akuntan yang sering terlibat dalam fraud adalah Arthur Andersen yang mayoritas melakukan skema earning manajemen dan manipulasi laporan keuangan. Bahkan mahasiswa menyatakan bahwa KAP besar tersebut dibayar mahal oleh klien, sehingga loyalnya untuk kepentingan klien dan mengabaikan perilaku etisnya. Artinya etika ditinggalkan oleh para akuntan demi mengejar setoran, sehingga akuntan yang pada awalnya dianggap professional namun sekarang cenderung komersial. 
Beberapa kasus yang terjadi di Indonesia yang dijelaskan oleh mahasiswa diantaranya kasus PT. KAI, kasus Bank Lippo dan kasus PT. Telkom. Mahasiswa menyatakan bahwa PT.KAI selaku perusahan milik negara bertindak tidak transparan dalam melaporakan pertanggungjawaban keuangannya kepada public, meskipun PT.KAI telah diaudit oleh BPK dan juga oleh akuntan public. Dalam kasus Bank Lippo, mahasiswa menyatakan bahwa Bank Lippo telah membuat laporan keuangan ganda dengan posisi keuangan yang berbeda dalam waktu yang berdekatan. Menurut mereka, hal ini menunjukkan adanya kecurangan dalam pelaporan keuangan, meskipun Bank Lippo telah diaudit oleh akuntan public. Sedangkan dalam kasus PT.Telkom, mahasiwa menjelaskan bahwa PT.Telkom melakukan pergantian KAP yang mengauditnya, dari akuntan yang lama menunjukkan adanya beberapa akun yang tidak dapat dipertanggungjawabkan, serta penyajiannya yang belum sesuai dengan standar akuntansi yang berlaku di New York Stock Exchange. KAP yang mengaudit PT.Telkom dianggap tidak kompeten.

\section{Sikap yang ditunjukkan oleh mahasiswa ketika menghadapai tindakan yang menimbulkan dilema etis}

Dalam menjawab scenario kasus yang berkaitan dengan dilemma etis, awalnya mahasiswa terlihat bingung dalam mengutarakan persepsinya. Mahasiswa tingkat 3 yang telah menempuh mata kuliah auditing serta etika bisnis dan profesi akuntansi dalam memberikan persepsinya terlihat berpikir lebih dahulu sebelum menerima pekerjaan rumit yang tidak sesuai dengan kemampuannya dan tidak dilakukan pengawasan dalam pekerjaan tersebut. Mereka mempertimbangkan untuk mencari orang lain yang lebih tahu untuk diminta kerjasamanya serta mengarahkan mereka saat melakukan pekerjaan yang rumit serta kompleks tersebut.

\section{Keputusan yang diambil oleh mahasiswa berkaitan dengan scenario dilema etis}

Berdasarkan persepsi dan pengamatan yang dilakukan pada mahasiswa tingkat 3 yang telah menempuh mata kuliah auditing serta etika bisnis dan profesi akuntansi dalam memberikan persepsinya terlihat sangat mempertimbangkan aspek-aspek pengambilan keputusan yang etis. Menurut pendekatan five questions yang mencakup is it profitable, is it legal, is it right, is it fair dan is it sustainable development menunjukkan bahwa mahasiswa tersebut telah memahami nilai-nilai etika. Hal ini dapat dilihat saat adanya pemberian tugas rekonsiliasi yang sangat kompleks dan rumit, serta terbatasnya waktu yang diberikan, maka mahasiswa tersebut memberikan persepsi menerima pekerjaan namun dengan mempertimbangkan berbagai hal. Diantaranya mahasiswa memberikan persepsi bahwa mereka kan meminta bantuan teman lain yang lebih mengerti tentang pekerjaan tersebut serta memberikan pengarahan. Mahasiswa tersebut juga memberikan persepsi bahwa mereka akan mengajukan waktu yang diperlukan agar dapat memnuhi pekerjaan tersebut tanpa melanggar prosedur yang seharusnya dilakukan dalam pekerjaan rekonsiliasi yang rumit dan kompleks tersebut. Pertimbangan tersebut dilakukan agar keputusan yang diambil dapat menguntungkan semua pihak, wajar, legal, tidak melanggar hak orang lain serta untuk keberlanjutan.

Berdasarkan teori etika, persepsi yang diberikan oleh seseorang terhadap sebuah keputusan dengan 
mempertimbangkan berbagai konsekuensi yang mencakup kepentingan orang lain maka dapat dikategorikan sebagai tipe utilitarianisme. Tipe tersebut cenderung dalam bertindak ataupun mengambil keputusan mempertimbangkan kepentingan orang lain dan memberikan manfaat bagi orang lain.

\section{KESIMPULAN DAN SARAN}

Berdasarkan hasil penelitian menunjukkan bahwa mahasiswa tingkat 3 yang telah menempuh mata kuliah auditing serta etika bisnis dan profesi akuntansi menunjukkan persepsi bahwa mereka akan mempertimbangkan terlebih dahulu sebelum menerima tugas yang rumit dan kompleks tersebut. Mahasiswa tersebut berusaha mengambil keputusan yang dipandang etis. Dengan adanya keterbatasan hasil penelitian, yaitu scenario kasus yang berkaitan dengan dilemma etis hanya dipersepsikan oleh mahasiswa akuntansi tanpa dengan adanya praktik ilustrasi pekerjaan yang ada di dalam scenario tersebut. Hal ini terjadi karena penelitian ini memfokuskan pada reaksi mahasiswa ketika diberikan scenario kasus yang menimbulkan dilemma etis. Oleh karena itu, beberapa saran yang bagi penelitian selanjutnya adalah:

1. Diharapkan melakukan penelitian dengan melalui eksperimen atas scenario kasus, sehingga dapat melihat reksi responden lebih mendalam.

2. Penelitian dilakukan tidak hanya kepada mahasiswa akuntansi, tetapi juga akuntan internal yang bekerja dalam perusahaan, dimana sebagai pihak yang berkaitan langsung dengan pekerjaan seperti yang dijelaskan dalam scenario kasus, sehingga dapat diperbandingkan bgaimana persepsi etis yang dimilikinya.

\section{DAFTAR PUSTAKA}

De George, R. T. (1999). Business ethics. Upper Saddle River, NJ: Prentice-Hall.

Esa, E., \& Zahari, A. R. (2015). the Relationship Between Personal Traits and Accounting Students Perception on Ethics and Love of Money : Case of Malaysian Government-Linked University, 5(8), 174-182. https://doi. org/10.18488/journal.1006/2015.5.8/1006.8.174.182

Fritzsche, D. J., and Becker, H. (1984). Linking management behavior to ethicalphilosophy - An empirical investigation. Academy of Management Journal,27, 166-175.

Ho, Y. H., \& Lin, C. Y. (2011). Ethical decision making of accounting students: a cross-cultural comparative study. International Journal of Business Governance and Ethics, 6(3), 294. https://doi.org/10.1504/ IJBGE.2011.043242

Johari, R., Saidi, N. (2013). The effect of ethical orientation and moral intensity on future's auditor ethical judgement. Academy of Management Review, 16, 366-395.

Kohlberg, L. 1976. Moral stages and moralization: The cognitive-development approach. In

Kitchener, K. S. (1984). Intuition, critical evaluation, and ethical principles: The foundation for ethical decisions in counseling psychology. The Counseling Psychologist, 12, 43-55. 
Kohlberg, L. (1981). Essays in moral development: The philosophy of moral development. New York: Harper \& Row. Kohlberg, L. (1984). The psychology of development. San Francisco, CA: Harper \& Row.

Onyebuchi, V. N. (2011). Perceptions of Male and Female Accounting Majors and Non-Accounting Majors on Ethics in Accounting. International Journal of Business \& Social Science, 2(17), 74-78. Retrieved from http:// ezproxy.library.capella.edu/login?url=http://search.ebscohost.com/login.aspx?direct=true\&db=bth\&A $\mathrm{N}=66502335 \&$ site $=$ ehost-live\&scope $=$ site

Rosnidah, I., Sulistyowati, W.A., Yulianto, A. (2016). The Effect of Ethical Orientation and Moral Intensity Toward Auditor Candidate's Ethical Decision. Proceedings of The $2^{\text {nd }}$ ICEAI, Vol.01, Number.01.

Simnett, R. (1996). The effect of information selection, information processing and task complexity on predecitive accuracy of auditors. Accounting, Organizations and Society. Vol.21,699-719

Sulistyowati, W.A. \& Yulianto, A. (2014). Intensitas mahasiswa akuntansi dalam melakukan blow-up kecurangan pelaporan keuangan: Sebuah eksperimen. Prosiding Seminar FKBI: Asean Economic Community 2015: Lust or Trust. 12 December 2014, Bandung, Indonesia.

T. Lickona (Ed.), Moral development and behavior: Theory, research and social issues (pp. 31-53). New York: Holt, Rinehart \& Winston.

Tsui, J. (1996). Auditors' Ethical Reasoning: Some Audit Conflict and Cross Cultural Evidence. The International Journal of Accounting.Vol.31,121-132.

Gambar 1

Kerangka Pemikiran

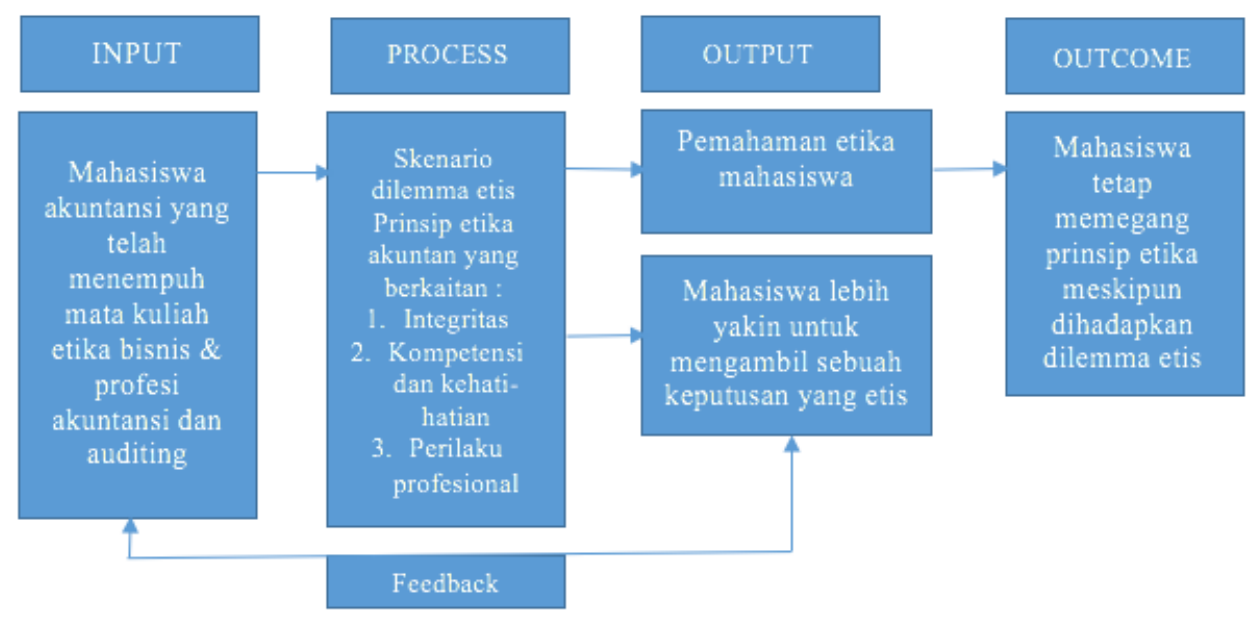

